\title{
Costs and Losses Imposed on California Ranchers by Yellow Starthistle
}

\author{
Alison J. Eagle, ${ }^{1}$ Mark E. Eiswerth, ${ }^{2}$ Wayne S. Johnson, ${ }^{3}$ Steve E. Schoenig, ${ }^{4}$ and \\ G. Cornelis van Kooten
}

Authors are ${ }^{1}$ Research Associate, Department of Economics, University of Victoria, PO Box 1700, STN CSC, Victoria, BC V8W 2 Y2, Canada; ${ }^{2}$ Associate Professor and University of Wisconsin Cooperative Extension State Specialist, Department of Economics, University of Wisconsin, Whitewater, WI 53190; ${ }^{3}$ Associate Professor and University of Nevada Cooperative Extension State Specialist, Department of Resource Economics, University of Nevada, Reno, NV 89557; ${ }^{4}$ Senior Environmental Research Scientist and Weed Eradication Program Manager, Integrated Pest Control Branch, California Department of Food and Agriculture, 1220 N Street, Sacramento, CA 95814; and ${ }^{5}$ Professor and Canada Research Chair, Department of Economics, University of Victoria, PO Box 1700, STN CSC, Victoria, BC V8W 2Y2, Canada.

\begin{abstract}
While the significant ecosystem damage caused by invasive weeds has been well documented, the economic consequences of specific invasive weed species are poorly understood. Yellow starthistle (Centaurea solstitialis L., hereafter YST) is the most widespread noncrop weed in California, resulting in serious damage to forage on natural range and improved pasture. A survey was administered to California cattle ranchers to investigate YST infestation rates, loss of forage quantity and value, and control or eradication efforts. The results were used to estimate countywide losses and costs for 3 focus counties, as well as statewide losses/costs, due to YST in California. Total losses of livestock forage value due to YST on private land for the state of California are estimated at $\$ 7.65$ million per year, with ranchers' out-of-pocket expenditures on YST control amounting to $\$ 9.45$ million per year. Together, these amount to the equivalent of $6 \%-7 \%$ of the total annual harvested pasture value for the state. Therefore, while the impacts are relatively small within the statewide total agricultural production system, losses and costs due to YST infestation do constrain California's livestock grazing sector.
\end{abstract}

\section{Resumen}

Mientras que el daño causado a los ecosistemas por las malezas invasoras ha sido bien documentado, las consecuencias económicas es especies especificas de maleza invasoras son pobremente entendidos. El "Yellow starthistle" (Centaurea solstitialis L., de aquí en delante YST) es la maleza de terrenos no cultivados más ampliamente dispersa en California, que produce un serio daño al forraje de los pastizales nativos y praderas mejoradas. Se aplicó una entrevista a los ganaderos de bovinos de carne de California para investigar las tasas de infestación de YST, las pérdidas en la cantidad de forraje y su valor y los esfuerzos de control o erradicación. Los resultados se usaron para estimar las pérdidas a nivel de municipal y los costos en tres municipalidades objetivo, así como las perdidas/costos a nivel estatal resultantes del YST en California. Las pérdidas totales de forraje de valor para el ganado de carne por el YST en terrenos privados del estado de California son estimadas en $\$ 7.65$ millones por año, y con los gastos realizados por los ganaderos para controlar el YST esta cantidad asciende a $\$ 9.45$ millones por año. En conjunto, estas cantidades equivalen al $6 \%-7 \%$ de valor total anual del forraje cosechado en el estado. Por lo tanto, mientras que los impactos son relativamente pequeños dentro del sistema de producción agrícola estatal, las pérdidas y costos debidos a la infestación de YST constriñen el sector ganadero de California.

Key Words: forage values, invasive weed economics, invasive weeds, nonnative species

\section{INTRODUCTION}

Nonindigenous invasive weed species can have substantial impacts on forage quantity and quality, increasing management costs, imposing land use changes, and thereby reducing ranch profitability. Environmental damage and losses due to the approximately 50000 nonindigenous species in the United States have been estimated at more than $\$ 136$ billion per year, with $\$ 6$ billion due to weeds in pastures (Pimentel et al. 2000). Although the impacts of invasive weeds on livestock grazing are significant, relatively few studies have estimated the economic effects of specific weed species on the ranching sector. Notable

This research was funded in part by a grant from the California Department of Food and Agriculture.

Correspondence: Mark E. Eiswerth, Department of Economics, University of WisconsinWhitewater, 800 W. Main St, Whitewater, WI 53190. Email: eiswertm@uww.edu

Manuscript received 24 May 2006; manuscript accepted 14 April 2007 exceptions include studies of leafy spurge (Euphorbia esula L.) (Leistritz et al. 1992; Leitch et al. 1996) and various species of knapweed (Centaurea diffusa Lam., C. maculosa Lam., and Acroptilon repens L.; Hirsch and Leitch 1996).

Yellow starthistle (Centaurea solstitialis L., hereafter YST), a Eurasian native believed to have been introduced in the mid19th century in imported contaminated alfalfa seed (DiTomaso and Gerlach 2000), is the most widely distributed noncrop weed in California (DiTomaso et al. 2000). It may now be found in much of the United States, although by far the heaviest infestations, in addition to California, are in other western states, including Idaho, Oregon, and Washington (USGS 2005; USDA 2006). Surveys of county agricultural commissioners reveal that the area in California infested by YST has increased significantly over the past 5 decades, from 1.2 million acres in 1958 to 1.9 million acres in $1965,7.9$ million acres in 1985, and 14.3 million acres in 2002 (Maddox and Mayfield 1985; Pitcairn et al. 2004). 
YST spreads via high rates of seed production, with dispersion aided by birds and, more commonly, human activities such as road building, construction, and the movement of contaminated vehicles, equipment, and horticultural soils. Each plant is capable of producing up to 100000 seeds (DiTomaso 2007) of which approximately 95\% are viable (Lass et al. 1999). A study conducted on YST in Idaho indicated the mean longevity of its pappus-bearing achenes in the soil was 10 years (Callihan et al. 1993); such longevity can pose challenges to YST control and/or eradication efforts.

Although YST provides some forage value in early growth stages, the spiny nature of the weed means that livestock and wildlife avoid grazing in heavily infested areas, as the spines cause damage and discomfort to grazing animals. A study conducted in the Sacramento Valley of California indicated that dry annual range infested with YST contains less crude protein and total digestible nutrients relative to dry annual range not infested with YST (Barry 1995). Prolonged ingestion of YST by horses causes a mostly fatal neurological disease called equine nigropallidal encephalomalacia (ENE) or "chewing disease" (Cordy 1978).

Burning, cultivation, mowing, timed grazing, application of chemical herbicides, and biological controls have been utilized in attempts to control YST. Regular prescribed burns and controlled grazing reduce YST seedbank stocks, seedling density, and mature vegetative cover, but, because seeds can remain viable for many years, new plants can establish in subsequent years (Thomsen et al. 1993; Kyser and DiTomaso 2002). One prescribed burning study conducted in California found that, following the cessation of the burning, the ecosystem transitioned back toward "conditions that favor the growth of yellow starthistle over that of the native forbs. This is indicated by rapid declines in vegetative cover, species richness, and diversity after burn cessation" (Kyser and DiTomaso 2002). The study therefore indicated that, "by most indices," burned grassland was not significantly different from unburned grassland after 3 years (Kyser and DiTomaso 2002). As a result of the ineffectiveness of individual control methods and the persistence of the YST seed bank, effective management may require a combination of methods on a long-term basis.

The principal objective of this article is to report the results of a survey that collects primary data on the damages that YST imposes on California ranchers. The survey data comprise baseline grazing revenues, grazing losses caused by YST, outof-pocket YST management costs, and other factors related to YST infestations as reported by ranchers. As such, they comprise the first comprehensive attempt to obtain such information.

The second objective is to combine the direct reports of surveyed ranchers with county-level data on YST infestation and land use, as well as other survey data, to estimate forage losses and mitigation costs 1) for the counties targeted by our survey and 2) statewide for California. Several assumptions, as well as supplemental sources of data, are necessary in order to extrapolate the results of the survey to the statewide level. To reflect appreciable uncertainty in the resulting estimates, we use standard errors of several key parameters to generate not only central point estimates of forage losses and mitigation costs but also the likely range of these values. Notwithstanding the uncertainty inherent in the estimates, we believe that the extrapolation exercise is informative and provides quite useful information given that such an exercise has so rarely been performed for any nonnative invasive weed species. Policymakers and land managers rarely have access to data on aggregate forage losses and mitigation costs of invasive species; the overall purpose of this article is to make such estimates available.

\section{METHODS}

\section{Survey Design and Administration}

We designed and administered the California Yellow Starthistle Survey: Economic Impacts on Agriculture (hereafter the Long Survey) to ranchers in California. The survey was reviewed by specialists at the California Department of Food and Agriculture and the California Cattlemen's Association and, after inclusion of their comments, was endorsed by both institutions. The process of survey administration began with pretesting in the spring of 2003 and continued with full implementation through the summer and early fall of 2003.

Respondents were able to complete surveys either by mail or via the Internet. To support implementation of the survey by mail, the California Cattlemen's Association provided lists of ranchers in the 3 counties of primary interest (Calaveras, Mariposa, and Tehama). Mail survey implementation then involved mail-outs to all cattle ranchers in these 3 counties (1076 in all). These counties were chosen because of the importance of livestock ranching and grazing to the agricultural economy of those counties and the expressed interest of ranchers in the YST problem as evidenced by their attendance and comments at focus meetings. The locations of the 3 counties are indicated in Figure 1, which also shows the extent of YST infestations in California. As is evident, our 3 priority targeted counties are among several in California that are experiencing substantial infestations of YST.

In addition, to reach ranchers thought to be most knowledgeable about invasive weeds, a second mode of implementation was employed. It involved, first of all, distributing information on how to participate in either hard copy or Internet versions of the survey to stakeholder groups in counties with significant levels of YST and livestock grazing. In particular, "survey notification cards" were sent to County Cooperative Extension, County Farm Bureau, and other offices in several counties so that these agencies could inform ranchers about how to complete the survey. Second, we attended 2 working group sessions at 2 meetings of the California Cattlemen's Association, where we were invited to distribute hard copies of the survey as well as information on how to complete the survey online. The completed surveys received from outside of the 3 targeted mail-out counties resulted from these efforts. This allowed for a broader, more diverse spectrum of statewide responses for comparison while targeting ranchers knowledgeable about YST.

With a nonrandom survey, the possibility for selection bias is always present. In particular, one might expect a tendency for those ranchers with the worst YST problems to be the most likely to complete the survey. With an eye toward this possibility, we assessed the relationship between ranchers' self-reported YST prevalence (in a particular county) and 


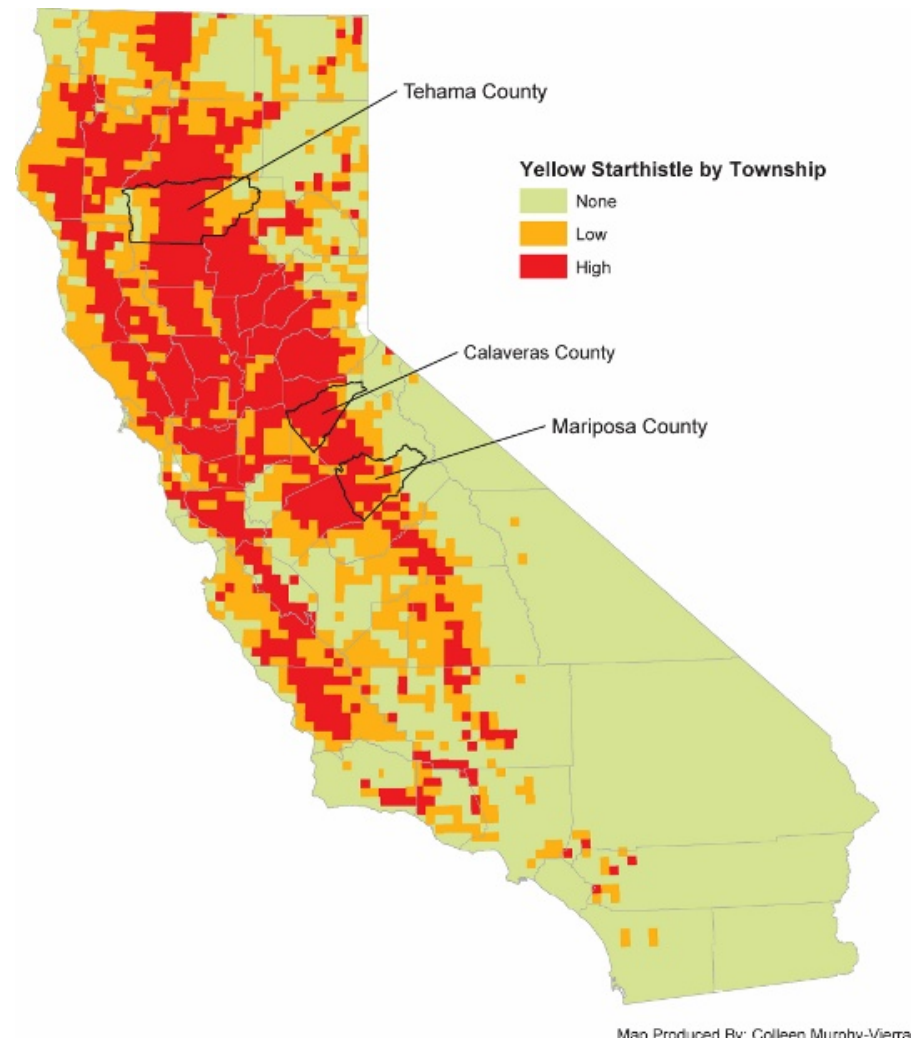

Figure 1. Map of yellow starthistle infestations in California, showing the 3 counties targeted in the mail-out survey of ranchers.

independent estimates of YST prevalence by county. As described in the "Results" section, we find no evidence of overrepresentation of those ranchers with the heaviest YST infestations.

In terms of content, the survey gathered detailed information from ranchers on topics related to livestock grazing and YST infestation and control. First, general information was collected with respect to grazing practices, number of animals grazed, basic ranch characteristics, and demographic attributes of the ranchers. Second, a question was included to determine what the average per-acre grazing net revenues (i.e., without YST baseline) would typically be for each rancher on various types of rangeland/pastureland. Third, the survey posed questions specific to YST infestation on each rancher's rented and owned lands. On this point, the survey first asked ranchers to estimate the number of acres they manage that was infested to any extent with YST. Then the ranchers were asked to estimate the average percent cover of YST on those infested acres. This sequence of questioning is intended to reduce the guesswork that respondents might otherwise face in determining what is meant by the term "infestation." Fourth, a question was included that asked ranchers for their best estimates of the percent decline in forage (grazing) yield caused by the presence of YST on their lands. Fifth, questions were included to ascertain rancher out-of-pocket expenses for YST control, types of YST control strategies utilized, and other actions taken in response to YST infestation (e.g., purchasing additional feed for livestock or shifting livestock to another grazing area). Finally, the survey requested ranchers' opinions on recreation and wildlife impacts of YST and the potential for different weed management programs.
The survey contained separate modules for eliciting data for private and public lands. However, since the majority of respondents managed private lands (294 respondents vs. 33 for public land), the focus here is on YST impacts on private grazing lands.

\section{Estimating Aggregate Economic Losses}

The survey results were combined with county-level data on forage production area (CASS 2001) to estimate aggregate economic losses and costs due to YST for Calaveras, Mariposa, and Tehama counties and also for the state of California as a whole. These calculations include only economic losses related to grazing land, thereby excluding other economic losses imposed by YST, such as those associated with increased water uptake by YST plants, damages to native plant habitat, and impaired outdoor recreation activities (e.g., hiking and trail riding). That is, the economic losses estimated here are limited strictly to reductions in grazing opportunities for domestic livestock and related weed control expenses.

Aggregate losses in ranchers' net revenues due to YST were developed as follows. First, the survey directly asked ranchers what the average per-acre grazing net revenues (without YST) would be on their lands, differentiated by type of range/pasture. Second, the survey also asked ranchers for their best estimates of the decrease in forage (grazing) yield caused by the presence of YST on their lands in the most recent year. Combining these 2 data elements allowed for the estimation of the mean YSTinduced reduction in net revenue per acre from livestock operations. Third, data on the total production area of rangeland and pastureland, by county, are available from the California Agricultural Statistics Service (CASS 2001). Combining all these data enabled the estimation of annual losses in net grazing revenues due to YST in the 3 focus counties as

$$
L_{i}=Y^{n r} \eta^{n r} A_{i}^{n r}+Y^{i p} \eta^{i p} A_{i}^{i p}
$$

where $L_{i}=$ annual loss in net revenues from grazing in county $i$, in dollars per year;

$Y^{n r}=$ baseline net revenue on native range in the absence of YST and other weeds, in dollars per acre per year (as reported in responses to the Long Survey);

$\eta^{n r}=$ reduction in forage (grazing) yield caused by YST on native range, as a proportion of total yield (as reported in responses to the Long Survey);

$A_{i}^{n r}=$ harvested area of "pasture, range" in county $i$, in acres (from CASS 2001);

$Y^{i p}=$ baseline net revenue on improved pasture in the absence of YST and other weeds, in dollars per acre per year (as reported in responses to the Long Survey);

${ }^{1} A_{i}^{n r}$ and $A_{i}^{\text {ip }}$ come from CASS (2001). Since the CASS data separates grazing land into range and irrigated components, we used irrigated area as a proxy for improved pasture. This underestimates the losses on improved pasture and on irrigated pasture for 2 reasons. The losses on improved pasture are underestimated because much of the actual improved pasture area is likely included in the CASS "pasture, range" area, which in this analysis has the lowest grazing value ( $\$ 6.11$ per acre). The losses on irrigated land are underestimated because the value from the survey for improved land is $\$ 16.75$ per acre, while the reported value from CASS (2001) for irrigated pasture averages $\$ 96.60$ per acre. Losses specific to irrigated pasture were not calculated because YST infestation is not as major an issue on irrigated land as elsewhere. 
$\eta^{i p}=$ reduction in forage (grazing) yield caused by YST on improved pasture, as a proportion of total yield (as reported in responses to the Long Survey); and

$A_{i}^{i p}=$ harvested area of "pasture, irrigated" land in county $i$, in acres (from CASS 2001).

Losses in grazing net revenues for Calaveras, Mariposa, and Tehama counties were computed using survey data and Equation [1] because the survey provides the best available picture to date of YST infestation rates and yield losses. Both baseline net grazing revenue $\left(Y^{n r}\right.$ and $\left.Y^{i p}\right)$ and reduction in forage yield due to YST $\left(\eta^{n r}\right.$ and $\left.\eta^{i p}\right)$ were derived directly from the survey responses provided by the ranchers.

While the survey collected information on individual experiences in nontarget counties, the area represented by respondents from those counties was insufficient to give a clear picture of the YST infestation rates statewide. Therefore, to extrapolate to all of California, we integrated the survey and county grazing acreage data with estimates of the extent of YST infestation throughout the state, as explained next.

First, the average losses in grazing net revenues per acre due to YST (as reported by the respondents) provided the best estimates to date of the ranch-level reductions in forage caused by YST. One might think that scientists would have conducted field studies at the ranch level to measure forage losses, but that is not the case, at least to date. Second, estimates of YST infestation area by county were drawn from Pitcairn et al. (2004), based on information reported by California county agricultural commissioners and their staff. Third, the proportion of YST infested area that has historically been used as grazing land was estimated through a second survey (administered in 2004 and again in 2006)—the Short Survey on Yellow Starthistle and Grazing Lands in California. This survey collected information from county agricultural commission experts and weed management area representatives in 35 California counties, targeting those with the largest YST infestations and the largest amounts of rangeland. The survey asked each respondent to estimate the fraction of YST-infested area in their county that has historically been used as grazing land as opposed to forestland or steep terrain unsuitable for grazing. Since uncertainty is involved in estimating this proportion, the survey allowed respondents to indicate ranges of percentages $(0 \%-10 \%, 11 \%-20 \%$, and so on) in which they believe the true proportion lies. While it would be preferable to have more exact estimates (e.g., from satellite imaging or GPS data), such data are currently not available.

Data for the statewide analysis was thus collected from: 1) the California Yellow Starthistle Survey: Economic Impacts on Agriculture (Long Survey), 2) the Short Survey on Yellow Starthistle and Grazing Lands in California (Short Survey), 3) grazing production area from CASS (2001), and 4) YST infestation area by county from Pitcairn et al. (2004). Annual losses in net grazing revenues due to YST were estimated for California counties as follows and then summed for the state as a whole:

$$
L_{i}=\left(g^{n r} A_{i}^{n r}+g^{i p} A_{i}^{i p}\right) \delta_{i} W_{i}
$$

where $L_{i}=$ annual loss in net revenues from grazing in county $i$, in dollars per year; $g^{n r}=$ mean losses in grazing net revenues due to YST on native range (estimated from Long Survey results), in dollars per acre per year;

$g^{i p}=$ mean losses in grazing net revenues due to YST on improved pasture (estimated from the Long Survey results), in dollars per acre per year;

$\delta_{i}=$ amount of YST-infested land in county $i$ historically used for grazing (estimated from the Short Survey results), as a proportion; and

$W_{i}=$ area in county $i$ that is estimated to be infested with YST (from Pitcairn et al. 2004), in acres.

All other variables are as previously defined.

Next, we extrapolated the results of the survey to estimate the amount of money that ranchers are spending out of their own pockets to control YST. This is estimated for both the target counties and the entire state as

$$
e_{i}=c\left(A_{i}^{n r}+A_{i}^{i p}\right)
$$

where $e_{i}=$ out-of-pocket expenditures by ranchers to control YST in county $i$, in dollars per year;

$c=$ mean out-of-pocket expenditures by ranchers to control YST (statewide estimate from Long Survey results), in dollars per acre per year; and

$A_{i}^{n r}$ and $A_{i}^{i p}$ are as previously defined.

Note that the rancher expenditures in Equation [3] include only explicit outlays of money and exclude ranchers' cost of time spent managing YST, a potentially significant cost.

Extrapolation to the state level of both the annual losses in grazing revenue and out-of-pocket YST control expenses involves only 49 out of the 58 total California counties. This is because 9 counties-Alpine, Del Norte, Imperial, Inyo, Mono, Orange, San Bernardino, San Diego, and San Francisco-satisfy 1 or more of the following conditions: 1) no current infestations of YST, 2) extremely small YST infestations at present, or 3) lack of data on the acreage of grazed rangeland or pastureland. The estimation of impacts for the remaining 49 counties represents an analysis that pertains to those regions where YST invasion is a bona fide issue for livestock grazing operations.

\section{RESULTS}

Since survey effort was concentrated in Calaveras, Mariposa, and Tehama counties, these counties comprised $71 \%$ of the responses. In addition, ranchers in 30 other California counties completed and returned surveys, yielding a total of 302 surveys returned, 243 in hard copy and 59 from the Internet-based version. ${ }^{2}$ The response rates for the 3 priority targeted counties were as follows: $21 \%$ for Calaveras County, $19 \%$ for Mariposa County, and $20 \%$ for Tehama County. Since surveys were sent to all ranchers in those counties, these percentages also

${ }^{2}$ When pasture land managed by survey respondents was compared with CASS (2001) harvested pasture (range plus improved), we found that the survey covered approximately $42 \%$, $10 \%$, and $25 \%$ of the pasture in Calaveras, Mariposa, and Tehama counties, respectively. 
Table 1. Selected ranch characteristics, California Yellow Starthistle Survey, 2003.

\begin{tabular}{lc}
\hline Ranch characteristics & $\%$ of respondents ${ }^{1}$ \\
\hline Maximum elevation $<1500 \mathrm{ft}$ & $57.7 \%(n=279)$ \\
Maximum elevation $<2500 \mathrm{ft}$ & $81.0 \%(n=279)$ \\
Cattle grazing on range or forestland & $70.8 \%(n=298)$ \\
Cattle grazing on pastureland & $48.3 \%(n=298)$ \\
Other grazing stock & $57.0 \%(n=298)$ \\
Grow crops (other than pasture) & $29.9 \%(n=284)$ \\
Alfalfa/meadow hay for own use & $13.0 \%(n=284)$ \\
Own private land & $95.0 \%(n=298)$ \\
Lease private land & $39.5 \%(n=296)$ \\
\hline
\end{tabular}

${ }^{1}$ In this column, $n$ denotes the number of survey respondents who answered the question.

represent the proportions of all ranchers in the tricounty target area that responded.

With any survey such as this, the possibility for selection bias is always present. In particular, one might expect a tendency for those ranchers with the worst YST problems to be the most likely to return the survey. This could lead to an overstatement of the average costs and losses incurred by ranchers. To investigate this possibility, we examined the relationship between ranchers' self-reported YST prevalence (in a particular county) and independent countywide estimates of YST prevalence (from Pitcairn et al. 2004). The question is, Were ranchers with the worst YST problems overrepresented in the survey compared to those with lesser YST problems? A comparison of the self-reported ranch YST infestation data with the best available estimates of countywide infestation rates suggests that this was not the case. For example, for Tehama County, which accounted for the largest number of returned surveys (116 out of 302 ), the weighted mean infestation rate self-reported by the ranchers was $35 \%{ }^{3}$ This is actually lower, not higher, than the best external estimate of the proportion of grazing land in Tehama County that is infested with YST, which is $41 \%$ (Pitcairn et al. 2004). Similarly, for Calaveras and Mariposa counties, the ranchers' self-reported infestation rates are lower than the current countywide YST infestation estimates, but the divergences are even larger. Finally, for the other 30 "nontarget" counties from which surveys were received, the weighted mean self-reported infestation rate was $11 \%$. Again, the best available data on countywide infestation rates indicates that the aggregate infestation rate in these 30 counties is larger, at about $25 \%$ (Pitcairn et al.). In other words, we find no evidence that ranchers with the worst YST problems were overrepresented in the sample.

\section{Key Survey Findings}

The first component of the survey collected basic information about the ranching operation. Seventy-one percent of survey respondents graze cattle on rangeland or forestland, while $48 \%$ graze cattle on pastureland (Table 1). About $13 \%$ of the

\footnotetext{
${ }^{3}$ Note that when we say weighted mean infestation rate, this is computed as the sum of selfreported infested acres on the respondent ranches in that county divided by the sum of the ranch acres managed by the respondents in that county. Thus, the mean is weighted by acres rather than a simple mean of the calculated infestation rates across all ranches.
}

Table 2. Land area managed by survey respondents, California Yellow Starthistle Survey, 2003.

\begin{tabular}{lcc}
\hline Type of land & No. of respondents & $\begin{array}{c}\text { Mean area per respondent, } \\
\text { acres (SE in parentheses) }\end{array}$ \\
\hline Private land-owned & 283 & $1296(175)$ \\
Private land-leased & 117 & $2667(627)$ \\
Public land-leased & 31 & $14820(3726)$ \\
\hline
\end{tabular}

ranchers grow alfalfa or meadow hay for their own use. Most of these ranches lie at relatively low elevations, with more than $57 \%$ of operations below 1500 feet of elevation and $81 \%$ below 2500 feet of elevation. Of those respondents reporting management of private land, the average owned area was 1296 acres, and leased area was 2667 acres (Table 2). By and large, the ranchers manage mostly unirrigated land for both owned and leased private property, with the average respondent reporting that only about $15 \%$ of their land is irrigated $(n=264)$.

Next, the survey focused on the incidence of YST. Of the 294 respondents who manage private lands, $93 \%$ reported that there currently is, or at some point had been, YST on their land. (Unless otherwise noted, the statistics reported henceforth are for privately managed lands.) While $18 \%$ of respondents were unsure about the timing of YST appearance on their land, 63\% of those who did know indicated that the weed had first appeared after 1970. When asked to estimate YST cover (YST as a proportion of total vegetation) for 2000 and 2003, the majority of respondents (62\% in 2000, 64\% in 2003) indicated YST cover on infested land area to be less than 30\% (Figure 2), with no consistent or identifiable shift in cover categories over the 3-year period.

As described in the "Methods" section, numbers for baseline (without YST) forage productivity and YST impacts on forage yields were obtained directly from the ranchers' responses to the Long Survey; the results are summarized in Table 3. Estimated pasture yield declines due to YST varied between respondents from "minimal" to more than $50 \%$, with mean losses of $15.3 \%$ and $12.7 \%$ on native range and improved pasture, respectively. On native rangeland where the mean net revenue on grazing land not infested with YST (baseline net revenue) was approximately $\$ 6 \cdot \mathrm{ac}^{-1} \cdot \mathrm{y}^{-1}$, the estimated mean drop in net revenue due to YST infestation approached $\$ 1 \cdot \mathrm{ac}^{-1} \cdot \mathrm{y}^{-1}$. Because of higher baseline forage productivity on improved pasture $\left(\$ 16.75 \cdot \mathrm{ac}^{-1} \cdot \mathrm{y}^{-1}\right)$, absolute dollar losses per acre were more than double that of native range. For target counties, the county-specific calculations of baseline net revenue and estimated yield losses due to YST were similar to survey-aggregate results, but survey-aggregate results for these parameters were utilized for all calculations.

In addition to calculating the forage yield losses, we report the percentage of ranchers who took certain actions in response to YST. These included efforts expended to compensate for decreased forage yield, such as purchasing additional hay, leasing additional grazing land (public and private), or selling livestock (Table 4). Even though we did not attempt to estimate quantitatively the costs associated with these changes, it is clear that many ranchers are incurring such adjustment costs. Some $55 \%$ of respondents reacted to YST-induced forage losses by 


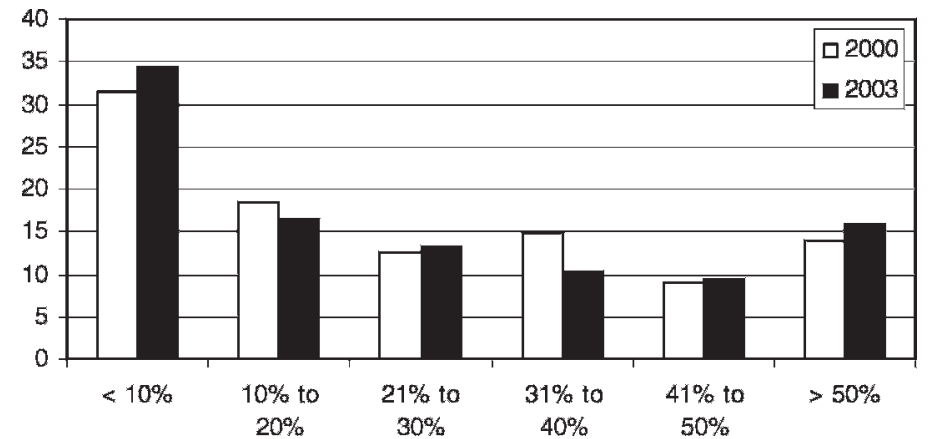

Figure 2. Estimated ground area covered by YST, as a proportion of total vegetation, on infested private land $(n=223$ [2000] and 212 [2003]).

selling animals and/or purchasing additional forage, with these responses much more likely $(P<0.001)$ from ranchers who reported higher yield losses. The most common response to YST was to take action to control weeds, and almost $60 \%$ of these respondents reported using chemical applications ( $\mathrm{Ta}$ ble 5), most often Roundup (glyphosate) and Transline (clopyralid). Mowing and timed grazing were also common practices for weed control, with methods such as biological control, burning, and cultivation also utilized.

Direct costs incurred by ranchers for YST control (exclusive of compensation for decreased forage yield and rancher's labor) were reported in the survey as out-of-pocket expenses. Among the 168 ranchers who reported monetary expenditures on YST management, the mean reported annual expenditure was $\$ 1247$. This was greater than the average of $\$ 374$ spent on YST control using federal and/or state funds, as reported by the survey respondents.

Of considerably greater meaning than average cost across ranches is the estimate of mean out-of-pocket control costs per grazing acre since it is that estimate (plus its standard error) that we use to generate "Low," "Central," and "High" estimates of control costs at the county and statewide levels. From the survey responses on costs, plus responses on the acreages of the individual ranches, we calculate that the mean out-of-pocket control cost per grazing acre managed is $\$ 0.55 \cdot \mathrm{ac}^{-1} \cdot \mathrm{y}^{-1}$. The weighted standard error of cost per

Table 3. Baseline grazing productivity and impacts of YST (SE in parentheses), California Yellow Starthistle Survey, 2003.

\begin{tabular}{|c|c|c|}
\hline \multirow[b]{2}{*}{ Characteristic/parameter } & \multicolumn{2}{|c|}{ Type of grazing land } \\
\hline & Native range & Improved pasture \\
\hline $\begin{array}{l}\text { Mean net revenue of } \\
\text { grazing land not infested } \\
\text { with YST or other } \\
\text { invasive weeds }\end{array}$ & $\begin{array}{c}\$ 6.11 \cdot a c^{-1} \cdot y^{-1} \\
(\$ 0.38)\end{array}$ & $\begin{array}{c}\$ 16.75 \cdot a c^{-1} \cdot y^{-1} \\
(\$ 1.75)\end{array}$ \\
\hline $\begin{array}{l}\text { Mean decrease in forage } \\
\text { yield attributable to YST }\end{array}$ & $15.3 \%(1.0 \%)$ & $12.8 \%(1.4 \%)$ \\
\hline $\begin{array}{l}\text { Mean decrease in net } \\
\text { revenue attributable to } \\
\text { YST }\end{array}$ & $\$ 0.93 \cdot \mathrm{ac}^{-1} \cdot \mathrm{y}^{-1}$ & $\$ 2.14 \cdot \mathrm{ac}^{-1} \cdot \mathrm{y}^{-1}$ \\
\hline
\end{tabular}

Table 4. Actions taken by ranchers in response to YST-related forage losses on private land $(n=246)$, California Yellow Starthistle Survey, 2003.

\begin{tabular}{lc}
\hline Action & $\%$ of respondents \\
\hline Purchase additional hay for feeding & $46.8 \%$ \\
Increase public grazing allotment & $0.0 \%$ \\
Lease additional private land for grazing & $12.2 \%$ \\
Sell livestock to reduce herd size & $21.5 \%$ \\
Take action to control weeds & $83.3 \%$ \\
\hline
\end{tabular}

managed acre (used to generate the $95 \%$ confidence interval for this parameter) is $\$ 0.13 \cdot \mathrm{ac}^{-1} \cdot \mathrm{y}^{-1}$.

Finally, given the already considerable length of the survey, we did not ask ranchers specifically about whether they thought control efforts were cost effective or whether YST infestations were manageable over the longer run. Nonetheless, some insight to these issues may be gleaned by responses to an open-ended question that allowed ranchers to provide various comments. From the responses, it seems clear that most ranchers feel that they have little choice but to continue managing for YST, otherwise the productivity of rangelands would deteriorate even further. Some ranchers also expressed concern that further YST infestation could jeopardize nonmarket values of land, indicating that the land has value to them not only as forage for livestock. This suggests that management efforts are somehow worth undertaking if both market and nonmarket values are taken into account. Not surprisingly, some ranchers mentioned that it would be useful if management costs were lower (e.g., lower price of herbicide treatments) or subsidized. Some ranchers also felt that various levels of government should do more, such as spraying along public rights of way.

\section{Estimates of Aggregate Economic Losses From YST}

Since 2 of the target counties, Tehama and Calaveras, had sufficient responses to calculate dependable county-specific values of mean grazing revenue and grazing yield losses due to YST, total losses were calculated first using these countyspecific parameter values and then compared to the losses calculated using survey-aggregate (multiple county) values for the 2 parameters. Forage losses were calculated to be $\$ 367000$ (Calaveras) and \$916000 (Tehama) using survey-aggregate values and \$289000 (Calaveras) and \$1062000 (Tehama) using county-specific data. The sum of the 2 county grazing loss estimates using the survey-aggregate values for the parameters

Table 5. Actions taken by ranchers to control YST on private land $(n=198)$, California Yellow Starthistle Survey, 2003.

\begin{tabular}{lc}
\hline Action & $\%$ of respondents \\
\hline Chemical application & $59.6 \%$ \\
Roundup (glyphosate) & $32.3 \%$ \\
Transline (clopyralid) & $23.7 \%$ \\
Mowing & $46.5 \%$ \\
Timed grazing & $34.9 \%$ \\
Cultivation & $20.2 \%$ \\
Prescribed burning & $19.2 \%$ \\
Biological control & $16.2 \%$ \\
\hline
\end{tabular}


Table 6. YST annual loss and cost estimates for Calaveras, Mariposa, and Tehama counties added together, 2003. ${ }^{1}$

\begin{tabular}{|c|c|}
\hline Category of loss/cost & Estimated YST losses and costs \\
\hline \multicolumn{2}{|l|}{ Losses due to reduced forage for livestock } \\
\hline As per Equation [1] & $\$ 1.72$ million \\
\hline As per Equation [2] & \\
\hline \multicolumn{2}{|l|}{ Rancher out-of-pocket expenditures for YST } \\
\hline control (excluding time cost of labor) & $\$ 0.98$ million \\
\hline Subtotal losses/costs & $\$ 1.98-\$ 2.70$ million $\cdot y^{-1}$ \\
\hline \multicolumn{2}{|c|}{$\begin{array}{l}\text { 1The estimates of lost forage in this table are based in part on extrapolations using data for } \\
\text { harvested pasture acreage by county. The area of pasture that would be harvested if YST } \\
\text { did not exist is not observable but would presumably be higher than the current level as } \\
\text { the extensive margin would be expanded. Therefore, estimates of losses would also be } \\
\text { higher. In addition, the estimated "subtotal" losses and costs only include the loss/cost } \\
\text { components included in the table and exclude other lost economic values (e.g., water } \\
\text { losses, losses in outdoor recreation activity, lost ecosystem service flows such as soil } \\
\text { retention, nutrient cycling, biodiversity, and so on), public expenditures on YST } \\
\text { management, and several components of private expenditure on YST control. }\end{array}$} \\
\hline
\end{tabular}

is thus about $5 \%$ lower than the sum of the estimates derived using the county-specific parameters. The reasonably similar range of results confirms the appropriateness of using surveyaggregate data for these counties and the rest of the state.

Calculations of total financial losses due to reduced forage and YST control expenditures in the targeted tricounties are provided in Table 6. Annual losses due to reduced forage for livestock were estimated at between $\$ 1$ million and \$1.7 million, although the true value is most likely closer to the higher estimate because of the larger number of respondents (answers from $>200$ ranchers used for Equation [1] versus estimates from a smaller number of professionals contributing to 1 of the parameters in Equation [2]) and the fact that the ranchers work more closely with the land in question. However, the similarity of the tricounty estimates derived from the 2 equations provides positive validation of our use of Equation [2] to develop statewide loss estimates. Out-of-pocket rancher expenditures on YST control in Tehama, Calaveras, and Mariposa counties are estimated to be about $\$ 1$ million annually, about the same as the estimated losses due to reduced forage availability.

Table 7 presents estimates of the statewide forage losses and rancher costs. The central estimate of statewide YST-caused losses due solely to reduced forage for livestock is $\$ 7.65$ million per year. The central estimate of statewide rancher out-ofpocket costs for YST control (excluding time cost of labor) is $\$ 9.45$ million annually. The sum of these estimates is $\$ 17.1$ million per year. "Low" and "High" estimates of both forage losses and out-of-pocket control costs are derived using $95 \%$ confidence intervals (i.e., \pm 2 standard errors) for the estimates of several key parameters in the equations: mean net grazing revenues per acre in the absence of YST, mean decrease in forage yield attributable to YST, and mean per acre YST control expenditures by ranchers. The resulting estimates range from $\$ 10.65$ million (Low) to $\$ 23.86$ million (High) per year. The central estimate of losses plus costs induced by YST on grazing lands ( $\$ 17.1$ million) amounts to $6.3 \%$ of the total harvested pasture grazing value of $\$ 272$ million for the state of California (CASS 2001).

Total costs to grazing agriculture due to YST (forage loss plus control costs) in the 3 focus counties (Calaveras,
Table 7. California YST annual loss and cost estimates, 2003. ${ }^{1}$

\begin{tabular}{|c|c|c|c|}
\hline \multirow[b]{2}{*}{ Category of loss/cost } & \multicolumn{3}{|c|}{ Estimated annual YST losses and costs } \\
\hline & $\begin{array}{l}\text { Lower } \\
\text { estimate }\end{array}$ & $\begin{array}{c}\text { Central } \\
\text { estimate }\end{array}$ & $\begin{array}{l}\text { Higher } \\
\text { estimate }\end{array}$ \\
\hline $\begin{array}{l}\text { Losses due to reduced forage } \\
\text { for livestock }\end{array}$ & $\$ 5.70$ million & $\$ 7.65$ million & $\$ 9.91$ million \\
\hline $\begin{array}{l}\text { Rancher out-of-pocket } \\
\text { expenditures for YST control } \\
\text { (excluding time cost of labor) }\end{array}$ & $\$ 4.95$ million & $\$ 9.45$ million & $\$ 13.95$ million \\
\hline Subtotal losses/costs statewide & $\$ 10.65$ million & $\$ 17.10$ million & $\$ 23.86$ million \\
\hline
\end{tabular}

Mariposa, and Tehama) range between $7 \%$ and $16 \%$ of the total pasture revenue in those 3 counties (depending on the equation used) as compared to losses that run at about $6 \%$ of total pasture revenue statewide. Because of the greater prevalence and damage in the target counties (most notably Tehama County, where survey respondents indicated that $35 \%$ of private grazing land was infested), losses and control efforts understandably would have the highest relative (percentage) effects on ranching in such counties.

Although the statewide estimates exclude 9 of 58 California counties, these are unlikely to exhibit large rangeland damages due to YST infestation; therefore, the forage loss and mitigation cost estimates presented here are likely to increase only slightly by including impacts in these counties, and then only as YST continues to spread. More important, our estimates do not include the opportunity cost of time that ranchers spend controlling YST, which might well be substantial. Finally, we provide no estimates of secondary impacts on regional economies of reduced grazing activity due to YST, and these can be important in some rural counties. For these and other reasons, the estimates should not be construed as representing the total economic impacts of YST caused by its negative effects on grazing.

\section{DISCUSSION}

Compared to Hartmans et al. (1997), who assumed a more than $80 \%$ reduction in range productivity due to YST in Idaho on the basis of 1 expert's opinion, our survey results indicated much lower reductions of about $15 \%$ and $13 \%$ on infested native range and improved pasture, respectively. Our survey results are more comparable, however, to those of more recent research by Eiswerth and van Kooten (2002) that uses the best professional judgments of weed scientists, county farm advisers, public land managers, and other specialists familiar with YST and its spread in California specifically. That study found, for example, that experts predicted forage losses of $6 \%-$ $10 \%$ for minimal infestations and $22 \%-28 \%$ for moderate infestations, with moderate infestation defined by most experts to be around $30 \%$ cover. Since the majority of the ranchers in our survey indicated that YST cover on their infested lands was 
less than $30 \%$, their self-reported estimates of forage losses of $10 \%-15 \%$ (on average) do not appear out of line with the best judgments of weed scientists and land managers as reported in Eiswerth and van Kooten (2002).

The economic value of grazing land from the survey results is somewhat lower than the average value reported by the CASS (2001). For example, where our survey found the average net revenue for native rangeland to be $\$ 6.11 \cdot \mathrm{ac}^{-1}$, the CASS statewide average value for rangeland was $\$ 9.32 \cdot \mathrm{ac}^{-1}$. By using the former rather than the latter values, this would tend to underestimate losses due to YST infestation.

Pimentel et al. (2000) calculated total US annual costs due to invasive weeds in pasture to be approximately $\$ 6.0$ billion, with the majority $(83 \%)$ of the costs a result of control efforts (as opposed to actual losses and damages). In our analysis, reported out-of-pocket costs due to YST control efforts for the 3 target counties were approximately $36 \%-49 \%$ of total annual forage losses plus mitigation costs, much less on a percentage basis than the Pimentel et al. estimate (although our estimates pertain only to 1 particular weed). In the statewide calculations, about $54 \%$ of the total annual losses/ costs were related to control costs rather than losses and damages. If control costs incurred by public agencies and damages experienced by other sectors were included, the ratios of costs to forage losses would be different.

While the losses and costs estimated in this article amount to between $6 \%$ and $7 \%$ of the total harvested pasture grazing value for the state of California, the estimates are not large relative to the $\$ 26$ billion contributed annually by the state's total agricultural sector. The absolute cost of YST may also seem less than one might expect given the pervasiveness of the weed in California. In light of our findings, it is important to note 2 factors. First, YST tends to invade and occupy ecological niches that typically offer relatively low per-acre values in agriculture, namely, semiarid grasslands. Therefore, though the relative impacts on those individual ranchers affected by YST are large, the aggregate monetary losses (e.g., due to reduced forage) may be lower than those associated with other nonnative weeds invading more productive agricultural lands. Second, it is important to remember that our analysis focuses only on livestock forage losses and out-of-pocket expenditures.

Importantly, it is useful to be aware that the monetary values of other negative impacts of YST may likely be greater than those examined here. For example, Gerlach (2004) provides a "rough preliminary estimate" indicating that the value of water lost to the Sacramento River watershed alone (due to higher rates of plant water uptake by YST relative to other vegetation) may range in the tens of millions of dollars annually. The monetary values of a suite of other ecological impacts (increased soil erosion, runoff of nutrients, losses in biodiversity, and so on), as well as depressed recreational activities (e.g., hiking, hunting), may also be substantial. However, these have not been documented to date for YST, and that represents a useful next step in research.

The results of this analysis lead to some policy implications for YST management. Many ranchers are spending appreciable amounts of money out of pocket to control YST. Along with the value of lost forage, the out-of-pocket costs amount to between $7 \%$ and $16 \%$ of the total pasture revenue in our 3 targeted counties, which is substantial relative to total grazing.
Still, it is clear that the effort to control YST is a difficult and long-term battle, given the way in which YST spreads easily across the landscape and the substantial life span of the typical YST seedbank. Ranchers' attempts to control YST with their own resources can be financially draining, especially given that YST control efforts need to be expended over a number of years before the full benefits of control accrue. A way to stabilize or lessen the aggregate statewide out-of-pocket costs is to focus on keeping YST-free regions uninfested and to promote yearly aggressive control of rebounding spot infestations within parcels that have undergone intensive 2-3-year control programs.

\section{MANAGEMENT IMPLICATIONS}

There remains a role for public intervention to control YST. First and foremost, control or eradication of invasive weeds is often a public good because such efforts reduce the negative spatial externalities-control of YST reduces the transboundary spillovers as 1 landowner's efforts to reduce YST lowers the potential magnitude of the problem on neighbors' fields. Relatedly, as discussed previously, the suite of costs/losses from YST outside the grazing sector (e.g., on recreational activities) are thought to be appreciable. Therefore, public expenditures/incentives for YST control on ranchers' lands are expected to yield public benefits for a diverse array of other natural resource service flows negatively impacted by YST. Finally, it is well known that a private landowner has a higher discount rate than that of society more broadly. Therefore, since spending on YST mitigation yields benefits that might not be realized for long periods, the private landowner has less incentive than the public authority to undertake the investment in weed control or, from a social perspective, underinvests in mitigation efforts. Taken together, the case for public intervention is stronger, especially in projects such as biocontrol technology that do not target specific parcels of land.

Given the pervasiveness of YST in some areas of California, the question arises as to whether to "give up" on control in such areas. It is possible that this is optimal for relatively small areas of low productivity with already heavy infestations, but we doubt that this is the case for larger areas of rangeland. In our conversations with ranchers and in the open-ended responses they have provided to the survey, we do not find much support for "doing nothing" (which may not be surprising). Rather, many ranchers feel strongly that control efforts must be strong and sustained. Our study results do not shed much light on this question, except to the extent that we have shown the range of probable costs/losses in 1 agricultural sector at a given point in time. However, given that YST control has public goods benefits and that losses (and future control costs) increase with time if control efforts are ignored, we find little justification at present for the notion that it is optimal to abandon control efforts on a large scale. It turns out that investments to control YST are optimal (Eiswerth et al. 2006), although an optimal response involves adaptive management that is flexible over time, treats YST on a repeated and sustained basis, chooses the response based on site-specific conditions, and is comprised of an ever-changing mix of control options rather than any one technology. 


\section{ACKNOWLEDGMENTS}

The contents of this manuscript do not necessarily reflect the views of the California Department of Food and Agriculture or any other organization with which any of the authors are affiliated. We thank Joseph DiTomaso of the University of California-Davis for suggestions and comments in the survey design phase of this project and Michael Pitcairn of CDFA for discussions regarding the initial findings and implications of the survey. We are indebted to Susan LaGrande of the California Cattlemen's Association for lending enthusiastic support to make implementation of the rancher survey a possibility. Finally, we thank Sue Strom of the University of Nevada and Carrie Bartzen of the University of Wisconsin for assistance with survey implementation and data entry and Colleen Murphy-Vierra at CDFA for assistance with infestation mapping. This project was funded in part by the Weed Management Area Program at CDFA.

\section{LITERATURE CITED}

BARRY, S. 1995. Cattle fecal fax. October Report, 7 November 1995. University of California Cooperative Extension Newsletter. Orland, CA: Glenn County University of California Cooperative Extension Office.

Callihan, R. H., T. S. Prather, and F. E. Northam. 1993. Longevity of yellow starthistle (Centaurea solstitialis) achenes in soil. Weed Technology 7:33-35.

[CASS] California Agricultural Statistics Service. 2001. County agricultural commissioners' data, 2001. Sacramento, CA: California Department of Food and Agriculture, Agricultural Statistics Branch.

Cordy, D. R. 1978. Centaurea species and equine nigropallidal encephalomalacia. In: R. F. Keeler, K. R. Van Kampen, and L. F. James [Eds.]. Effects of poisonous plants on livestock. New York, NY: Academic Press. p. 327-336.

DiTomaso, J. M. 2007. Yellow starthistle information. Available at: http:// wric.ucdavis.edu/yst/yst.html. Accessed 26 March 2007.

DiTomaso, J. M., and J. D. Gerlach. 2000. Centaurea solstitialis L. In: C. C. Bossard, J. M. Randall, and M. C. Hoshovsky [EDS.]. Invasive plants of California's wildlands. Berkeley, CA: University of California Press. p. 101-106.

Ditomaso, J. M., G. B. Kyser, S. B. Orloff, and S. F. Enloe. 2000. Integrated strategies offer site-specific control of yellow starthistle. California Agriculture $54: 30-36$.
Eiswerth, M. E., and G. C. van Kooten. 2002. Uncertainty, economics, and the spread of an invasive plant species. American Journal of Agricultural Economics 84:1317-1322.

Eiswerth, M. E., G. C. van Kooten, And J. M. Lines. 2006. Dynamic programming and learning models for management of a nonnative species. Victoria, BC, Canada: University of Victoria, Working Paper.

GerLach, J. D., JR. 2004. The impacts of serial land-use changes and biological invasions on soil water resources in California, USA. Journal of Arid Environments 57:365-379.

Hartmans, M. A., H. Zhang, and E. L. Michalson. 1997. The costs of yellow starthistle management. Moscow, ID: University of Idaho, Agricultural Experiment Station, Cooperative Extension Bulletin 793. 12 p.

HiRsch, S. A., AND J. A. Leitch. 1996. The impact of knapweed on Montana's economy. Fargo, ND: North Dakota State University, Agricultural Experiment Station, Agricultural Economics Report No. 355. 43 p.

Kyser, G. B., AND J. M. Ditomaso. 2002. Instability in a grassland community after the control of yellow starthistle (Centaurea solstitialis) with prescribed burning. Weed Science 50:648-657.

Lass, L. W., J. P. McCaffrey, D. C. Thill, and R. H. Callihan. 1999. Yellow starthistle: biology and management in pasture and rangeland. Moscow, ID: University of Idaho, Cooperative Extension Bulletin 805. 19 p.

Leistritz, F. L., F. Thompson, And J. A. Leitch. 1992. Economic impact of leafy spurge in North Dakota. Weed Science 40:275-280.

Leitch, J. A., F. L. Leistritz, and D. A. Bangsund. 1996. Economic effect of leafy spurge in the upper Great Plains: methods, models, and results. Impact Assessment 14:419-433.

Maddox, D. M., and A. Mayfield. 1985. Yellow starthistle infestations are on the increase. California Agriculture 39:10-12.

Pimentel, D., L. Lach, R. Zuniga, and D. Morrison. 2000. Environmental and economic costs of nonindigenous species in the United States. BioScience 50:53-65.

Pitcairn, M. J., S. Schoenig, J. Gendron, and R. Yacoub. 2004. Yellow starthistle continues its spread in California. California Agriculture 60:83-90.

Thomsen, C. D., W. A. Williams, M. P. Vayssiéres, F. L. Bell, and M. R. George. 1993. Controlled grazing on annual grassland decreases yellow starthistle. California Agriculture 47:36-40.

[USDA] U.S. Department of Agriculture. 2006. Plants profile: Centaurea solstitialis L. Available at: http://plants.usda.gov. Accessed 1 February 2006.

[USGS] U.S. Geological Survey. 2005. Centaurea solstitialis L. Available at: http:// el.erdc.usace.army.mil. Accessed 9 February 2005. 